\title{
高速引張加工されたステンレス鋼の機械的性質*
}

\author{
山田㦑**小寺沢啓司**杉田忠彰***
}

\section{Mechanical Properties of Rapidly Stretched Stainless Steels}

by

\author{
Iwao Yamada, Keiji Koterazawa and Tadaaki Sugita \\ (Himeji Institute of Technology, Himeji)
}

This investigation has been conducted to make clear the effect of strain rates on the internal structure and the mechanical properties of rapidly stretched stainless steels. The $18 \% \mathrm{Cr}-8 \% \mathrm{Ni}$ stainless steel and $17 \% \mathrm{Cr}-4 \% \mathrm{Ni} \mathrm{PH}$ stainless steel specimens have been used in this study.

The main results obtained are as follows :

(1) The yield strength and the tensile strength of these stainless steels in rapid tensile testing are larger than those in static tensile testing. The strain rate gives a remarkable effect on the resistance in deformation of these stainless steels.

(2) The yield strength, the tensile strength and the hardness of rapidly pre-stretched $18 \% \mathrm{Cr}$ $8 \% \mathrm{Ni}$ stainless steel are larger than those of statically pre-stretched sort. It was recognized that this fact is mainly due more to the promoting martensite transformation by rapid pre-stretching than by static one.

(3) The yield strength, the tensile strength and the hardness of statically pre-stretched $17 \% \mathrm{Cr}$ $4 \% \mathrm{Ni} \mathrm{PH}$ stainless steel are larger than those of rapidly pre-stretched sort. It seems that this fact is mainly due more to the promoting aging by static pre-stretching than by rapid one.

(4) From the above mentioned results, it is recognized that the mechanical properties of prestretched stainless steels are remarkably affected by the internal structure caused by the strain rate in pre-stretching.

(Received June 14, 1965)

\section{1 緒言}

高速変形に関する研究はすでにかなり多く行なわれ ているが，そのほとんどは衝撃荷重下の応力ーひずみ 線図の測定に関するもので，次の諸点に関する研究は きわめて少ないように思われる。

(a) 高速変形の機構が静的変形の機構と異なってい るかどうか.

(b) 高速変形を与えた場合には静的変形の場合と異 なった内部構造の変化が起てるかどうか。

(c) (a)(b)のような変化が起とるとすれば，それらが 高速加工材の機械的性質にぞのような影響を与えるか.

上述の諸点は相互に関連性のある問題であるが，強 度測定のみならず，乙れらの点もあわせて追求するて とによって高速変形の全ぼうがより明らかれされるも のと考光られ，作井博士もその必要性を強調している.

\footnotetext{
* 本報を「高速引張加工材つ機械的性質 (第 2 報)」(Mechanical Properties of Rapidly Stretched Materials II) とする 原稿受理 昭和 40 年 6 月 14 日

** 正会員 姫路工紧人学 姫路方伲伝居 $* * *$

筆者らはとのような観点から，すでに一連の研究を 実施しており，第 1 報として炭素鋼の場合を報告した。 すなわち，炭素鋼の場合にも，前加工速度の大小によ って内部構造の変化に相違を生じ，ひずみ速度のみな らずてのような内部構造の変化もまた変形抵抗に寄与 しているととを明らかにした。

衝撃荷重下のステンレス鋼の挙動に関する研究には, Clark \& Wood, Clark, 塚田 5), Baron, 作井 号, 河 田ら, Henriksen ら, および福井らのものなどがある が，やはり強度あるいは変形能（伸び）の測定のみに 重点が扔かれている、筆者らは前述の立場に立脚して, 炭素鋼について行なったと同様の実験をステンレス鋼 について実施し，二，三の知見を得たのでててに報告 する.

\section{2 試料および実験方法}

実験に用いた試料は18-8ステンレス鋼 (AISI 304) および17-4 PH鋼 (AISI 630) で，Table I はそれ らの化学成分である。試験片はFig. 1 のようで，いず れも旋削成形後溶体化処理を施した。 Table II は溶 体化処理材の機械的性質を示す。なお実験装置の詳細 については第 1 報を参照されたい，実験の順序は， 
Table I. Chemical compositions of specimens (\%).

\begin{tabular}{l|c|c|c|c|c|c|c|c|c}
\hline \multicolumn{1}{c|}{ Materials } & $\mathrm{G}$ & $\mathrm{Si}$ & $\mathrm{Mn}$ & $\mathrm{P}$ & $\mathrm{S}$ & $\mathrm{Ni}$ & $\mathrm{Cr}$ & $\mathrm{Cu}$ & $\mathrm{Nb}+\mathrm{Ta}$ \\
\hline $\begin{array}{c}\text { 18-8 stainless steel } \\
\text { (AlSl 304) }\end{array}$ & 0.07 & 0.43 & 1.19 & 0.023 & 0.014 & 9.09 & 18.43 & - & - \\
\hline $\begin{array}{c}\text { 17-4PH stainless stee1 } \\
\text { (AISl 630) }\end{array}$ & 0.04 & 0.62 & 0.28 & 0.026 & 0.017 & 4.21 & 16.92 & 4.05 & 0.27 \\
\hline
\end{tabular}

Table II. Mechanical properties.

\begin{tabular}{c|c|c|c|c}
\hline Materials & $\begin{array}{c}\text { Yield strength } \\
\left(\mathrm{kg} / \mathrm{mm}^{2}\right)\end{array}$ & $\begin{array}{c}\text { Tensile strength } \\
\left(\mathrm{kg} / \mathrm{mm}^{2}\right)\end{array}$ & $\begin{array}{c}\text { Elongation } \\
(\%)\end{array}$ & $\begin{array}{c}\text { Hardness } \\
\text { (D.P.N.) }\end{array}$ \\
\hline $18-8$ stainless stcel & 25.0 & 62.0 & 64.0 & 180 \\
\hline $17-4$ PH stainless steel & 70.0 & 112.5 & 9.7 & 315 \\
\hline
\end{tabular}

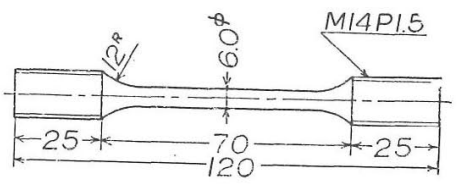

Fig. 1. Specimen $(\mathrm{mm})$.

(a) 溶体化処理材の静的引涱試颐 $\stackrel{* 1}{S}$ および高速引

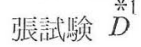

(b) 静的引张前加工材 $\stackrel{* 1}{*}$ ( $)$ の静的引張試験 $\stackrel{* 1}{S}$ およ び高速引张試験 $\stackrel{* 1}{D}$

(c) 高速引㖘前加工材 $\stackrel{* 1}{* 1}$ の静的引张陚験 $\stackrel{{ }^{*} 1}{S}$ およ び高速引張試験 $\stackrel{* 1}{D}$

これらの各場合について求めた荷重一伸び線図から， 耐力，引张強度，伸びなどを求ひ，前加工材について

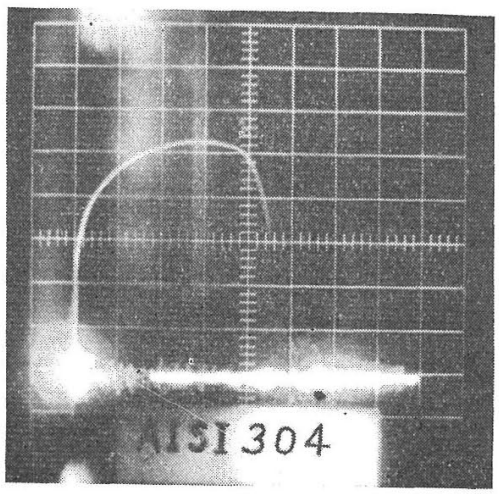

Fig. 2. Load-elongation diagram(Stress-strain diagram) for $18 \% \mathrm{Cr}-8 \% \mathrm{Ni}$-stainless steel (AISI 304).

*1 実験結黑の整理に上記のような符号を用いるとととする。した がって，たとえば(S)- $D$ は静的引張前加工材を引き続き高速引 張武験した場合を，(D)- $D$ は高速引張前加工材を引き続き高速 引張武験した場合を示す。

*2 詳練は文献 2 を参照されたい。
は硬度の測定わよびすべり蒂の発生の様相を顕貒鏡で 調べた。な㧍静的引張試験にはインストロン型の引張 試臨機を朋いた。 Fig. 2 は18-8ステンレス鋼の溶体化 処理材について得られた荷重一伸び線図の一例である が，そのほか荷重一時間線図，伸びー時間線図を求め，

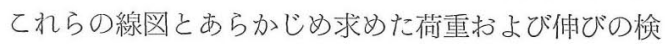
定曲線を用いて，ひずみ速度，耐才，引張强度などを 求めるととがでさる。

\section{3 実 験 結 果}

\section{$3 \cdot 1$ 機械的性質のひずみ速度依存性}

Fig. 3 (a) は18-8ステンレス鋼を低速（ $5 \mathrm{~mm} / \mathrm{min}$, $\left.\dot{\varepsilon}=1.7 \times 10^{-3} 1 / \mathrm{sec}\right)$ および高速 $(3.8 \mathrm{~m} / \mathrm{sec} ， \dot{\varepsilon}=76$ 1/sec)で引(張試験した場合の応力ーひずみ線図を，Fig.

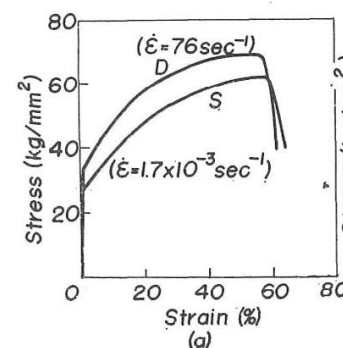

(a)

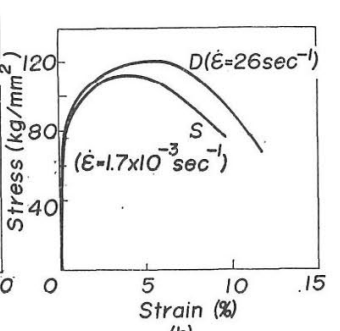

(b) (a) Stress-strain diagrams for $18 \% \mathrm{Cr}-8 \% \mathrm{Ni}$ stainless steel

(b) Stress-strain diagrams for $17 \% \mathrm{Cr}-4 \% \mathrm{Ni}$ PH stainless steel.

Fig. 3. Stress-strain diagrams for stainless steels in various strain rates.

3 (b) は 17-4 PH 鋼を低速 $\left(\dot{\varepsilon}=1.7 \times 10^{-3} 1 / \mathrm{sec}\right)$ お よび高速 $(1.3 \mathrm{~m} / \mathrm{sec}, \dot{\varepsilon}=26 \mathrm{1} / \mathrm{sec})$ で引張試験した場 合の応力ーひずみ線図を示す。両材料ともひずみ速度 が大きいほぞ耐力，引張強度が大きくなるが，全伸び については，18-8ステンレス鋼ではひずみ速度が大き いほうが小さくなるに反し，17-4 PH 鋼では逆に大 きくなる（よく佌びる）ととがわかる。 
Fig. 3 (a)のデータに加えて，さらにインストロン型 引張試験機を用いて引張速度 $100 \mathrm{~mm} / \mathrm{min}(\dot{\varepsilon}=3.3 \times$ $\left.10^{-2} 1 / \mathrm{sec}\right)$ の引張試験を実施し，ひずみ速度につい て耐力, 引張強度，全伸びを整理すると，Fig. 4のよ

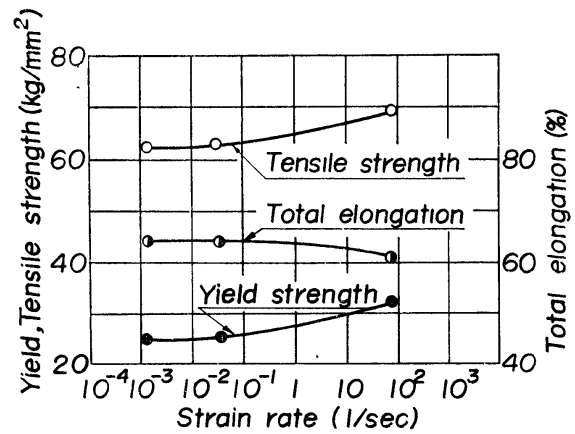

Fig. 4. Variation of mechanical properties of $18 \%$ $\mathrm{Cr}-8 \% \mathrm{Ni}$ stainless steel caused by strain rates.

うになり，前述の機械的性質にひずみ速度依存性のあ るととが一首明りょうになる。

\section{$3 \cdot 2$ 高速引張加工材の機械的性質}

静的あるいは高速引張加工した試験片を, 前加工し てから約 1 日経過後ふたたび静的あるいは高速引張試 験を実施した。 Fig. 5 (a)は静的引張前加工した18-8ス テンレス鋼 (S)を引き続き静的引張試験 $S$ した場合と 高速引張試験 $D$ した場合の応力ーひずみ線図を, Fig. 5 (b)は同じく高速引張前加工した18-8ステンレス鋼(D)

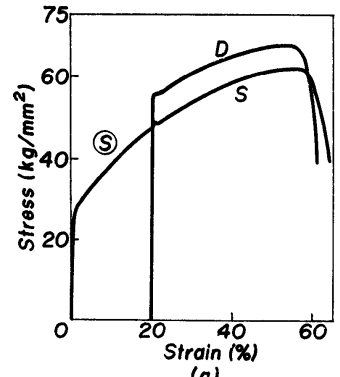

(a)

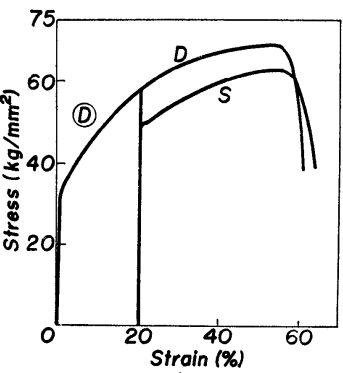

(b) (a) Static and rapid tensıon test for statically stretched specimen $(\varepsilon=20 \%)$

(b) Static and rapid tension test for rapidly stretched specimen $(\varepsilon=20 \%)$.

Fig. 5. Stress-strain diagram for $18 \% \mathrm{Cr}-8 \% \mathrm{Ni}$ stainless steel.

を引き続き静的引張試験 $S$ した場合と高速引張試験 $D$ した場合の応力ーひずみ線図である。（ただし，前 加工度はいずれも20\%である).

Fig. 5 から (S) と $S$, (D) と $D$ とは線図がほぼ連続 しているが, (S) と $D$, (D) と $S$ は著しく不連続であ るとと，前加工速度のいかんにかかわらず，引き続く 引張試験速度の早いほうが $\sigma-\varepsilon$ 線図のレベルが高い
ととがわかる．Fig. 6 は17-4 PH鋼に対する同様の実 験結果である。（ただし，前加工度はいずれも $2.5 \% の$

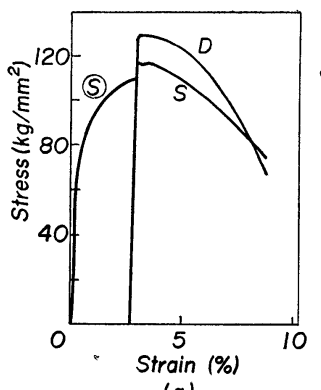

(a)

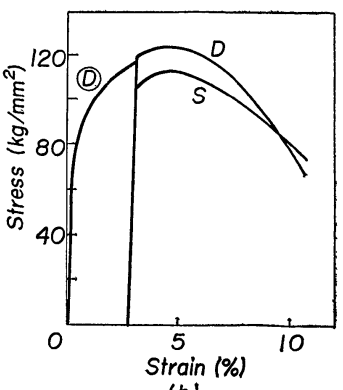

(b) (a) Static and rapid tension test for statically stretched specimen $(\varepsilon=2.5 \%)$.

(b) Static and rapid tension test for rapidly stretched specimen $(\varepsilon=2.5 \%)$.

Fig. 6. Stress-strain diagram for $17 \% \mathrm{Cr}-4 \% \mathrm{Ni}$ $\mathrm{PH}$ stainless steel.

場合である). Fig. 5 の場合と異なり, Fig. 6 の場合に はいずれも不連続な線図となっているが，引き続く引 張試験速度の早いほうが $\sigma-\varepsilon$ 線図で高いレベルを占 め，前加工材でもひずみ速度依存性を有するととは， 炭素鋼の場合および18-8ステンレス鋼の場合とまった く同じ傾向にある．Fig. 5，および 6 のような一連の 実験結果から，前加工に伴う耐力，弓張強度，伸びの 変化を示すとFig. 7，8，9，のようになる.

Fig. 7 (a)は18-8ステンレス鋼について, Fig.7(b)は17 -4 PH鋼について, 前加工度と耐力の関係を示したも のである．Fig. 7 (a)から18-8ステンレス鋼の耐力は前 加工速度のいかんにかかわらず，前加工に引き続いて 行なう引張試験速度が大きい場合のほうが高いレベル を占めているととがわかる，また引き続く試験速度が 同一のものに注目すると, 前加工度が同一であっても 静的前加工材 (S) よりも高速前加工材 (D) のほうがよ り強化されているてとが明らかである。

次に Fig. 7 (b)の17-4 PH鋼の場合の耐力は，18-8ス テンレス鋼の場合と異なり，わずかの前加工度で著し く上昇している. (S) $-S$ および (D) $-S$ 曲線よりも， (S)$D$, (D) $-D$ 曲線のレベルが高いととはFig. 7 (a)の場合 と同様であるが，前加工に引き続いて行なう引張試験 速度が同一の場合でも，(D) $S$ 曲線より $(S-S$ 曲線の ほうが，(D) $-D$ 曲線より (S) $-D$ 曲線のほうがいずれも 高いレベルを占めている，したがって，同一加工度で も高速引張前加工材 (D) よりも静的引張前加工材 (S) のほうが強化されており，乙のてとは18-8ステンレス 鋼の場合とまったく逆の関係にあるととはきわめて興 味のあることである.

以上の実験結果から前加工の際のひずみ速度の大小 

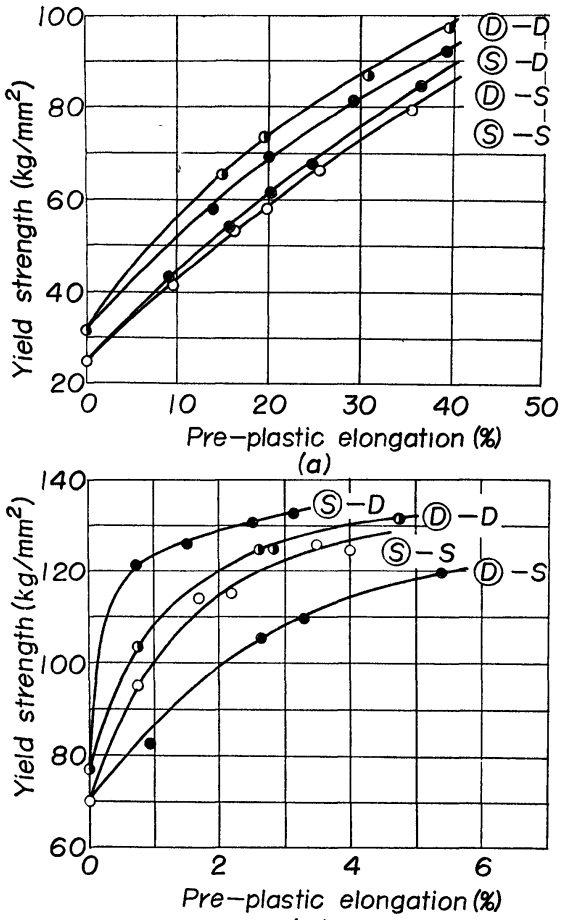

(b)

(a) Yield strength for $18 \% \mathrm{Cr}-8 \% \mathrm{Ni}$ stainless steel.

(b) Yield strength for $17 \% \mathrm{Cr}-4 \% \mathrm{~N} 1$ PH stainless stcel.

Fig. 7. Variation of yield strength with preplastic elongation caused by static and rapid tension.

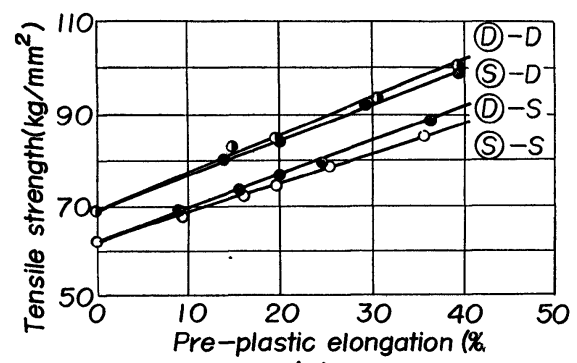

(a)

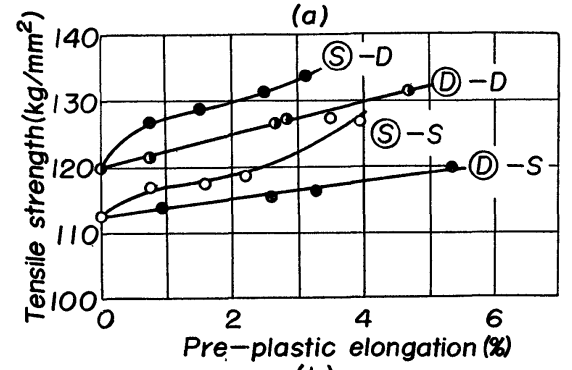

(b)

(a) Tensile strength for $18 \% \mathrm{Cr}-8 \% \mathrm{Ni}$ stainless steel.

(b) Tensile strength for $17 \% \mathrm{Cr}-4 \% \mathrm{Ni} \mathrm{PH}$ stainless steel.

Fig. 8. Variation of tensile strength with preplastic elongation caused by static and rapid tension,
によって，内部構造になんらかの相違点を生じた結果， 前加工に引き続く引張試験の際，耐力に上述のような 相違を与えたものと推定される。

Fig. 8 (a)は18-8ステンレス鋼, Fig.8(b)は17-4 PH鋼 の, 高速あるいは静的引張前加工による引張強度の変 化を示したもので, 前述の村力の場合と同様の傾向を 示している. ただ Fig. 8 (b)の場合の (S)-D, (S)-S 曲線, すなわち静的に前加工を与えた場合のみは直線関係に ないととがわかる。

Fig. 9 (a)は18-8ステンレス鋼の前加工度に伴う伸び の変化を, Fig. 9 (b)は同様17-4 PH鋼の場合を示す.

18-8ステンレス鋼では, 前加工の際のひずみ速度に無 関係で, (D) $-S$ と $(S)-S$ 曲線および (D) $-D$ と $(S)-D$ 曲 線はそれぞれぼほ 1 本の曲線に一致し，前加工に引き 続いて行なう弓張試験速度の早いほうが伸びが少ない ことがわかる，17-4 PH鋼では (D)-D，(D)-S 曲線は前 加工度が約 $3 \%$ 以上になるとほぼ一致し， (S) $-D$, (S)-S 曲線は約 $2 \%$ 以上なると一致しているが，上述の加 工度以下ではそれぞれ別個の曲線で示される。

Fig. 10は前加工に伴う硬度の変化を求めた結果で, Fig.10(a)は18-8ステンレス鋼の場合，Fig! 10(b)は17-4 $\mathrm{PH}$ 鋼の場合である.とれから18-8ステンレス鋼では 同一前加工でも，高速引張前加工材 (D) のほうがかた く, 静的引張前加工材 (S) のほうがやわらかいが，17 -4 PH 鋼ではこれとまうたく逆の関係にあり，(S)よ りも (D) のほうがやわらかい.

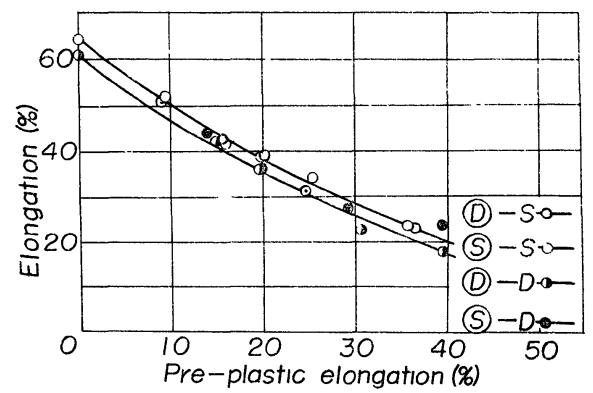

(a)

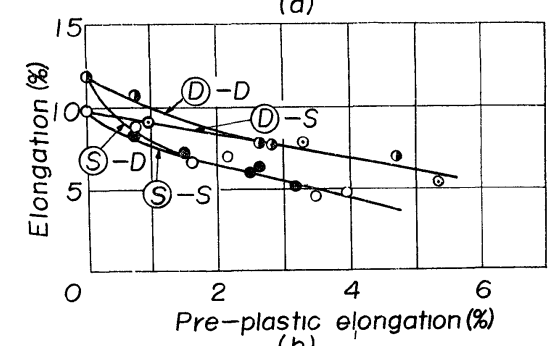

(b)

(a) Elongation for $18 \% \mathrm{Cr}-8 \% \mathrm{Ni}$ stainless steel.

(b) Elongation for $17 \% \mathrm{Cr}-4 \% \mathrm{~N}_{1} \mathrm{PH}$ stainless steel.

Fig. 9. Variation of total elongation with preplastic elongation caused by static and rapid tension. 


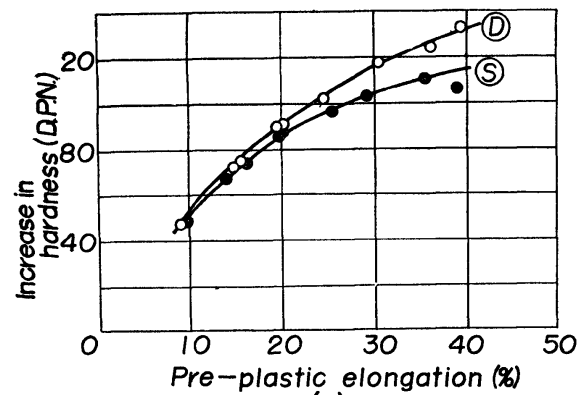

(a)

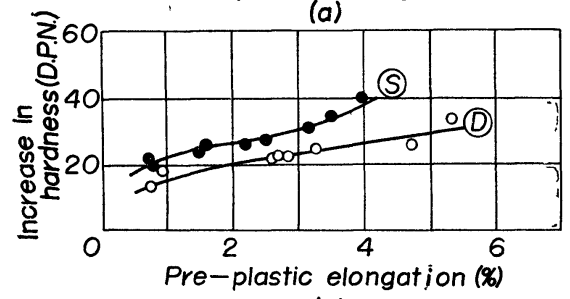

(b)

(a) Increase in hardness for $18 \% \mathrm{Cr}-8 \% \mathrm{Ni}$ stainless steel.

(b) Increase in hardness for $17 \% \mathrm{Cr}-4 \% \mathrm{Ni}$ PH stainless steel.

Fig. 10. Variation of hardness with pre-plastic elongation caused by static and rapid tension.

しかも，てのような前加工の際のひずみ速度の大小 による18-8ステンレス鋼および17-4 PH鋼の硬度の相 違は, 耐力, 引張強度, 伸びの各曲線に関して両材に 認められた相違と定性的によく対応しているととがわ かる。

\section{4 考察}

上述の実験から認められるおもな点を列挙すると次 のようである.

(a) 18-8ステンレス鋼，17-4 $\mathrm{PH}$ 鋼の溶体化処理材 の耐力, 引張強度などにひずみ速度依存性か認められ t.

(b) 引張前加工材の耐力, 引張強度については, 前 加工に引き続いて行なう引張試験速度が同一の場合, 18-8ステンレス鋼では静的引張前加工材に比べて高速 引張前加工材のほうが高い值を示すが，17-4 PHでは 逆に静的引張前加工材のほうが高い值を示す。

(c) 引張前加工材の硬度については，18-8ステンレ ス鋼では静的引張前加工材に比べて, 高速引張前加工 材のほうが高い值を示すが，17-4 PH鋼では逆に高速 引張前加工材のほうが低い值を示す。

(a)については炭素鋼の場合にも認められたてとであ り，ステンレス鋼についてもすでに多くの研究者によ って報告されている.

(b)(c)について共通している点は, 前加工材の機械的 性質が18-8ステンレス鋼と17-4 PH鋼とでは互いに相 反した関係にあることで，筆者らはもっぱらての点に 興味をひかれたので，ての点について考察した.

\section{4・1 18-8ステンレス鋼の場合}

まず，高速引張前加工材と静的引張前加工材のすべ り帯の発生状態を比較するために顕微鏡観察を行なっ たが，高速引張前加工材のほうがすべり帯がやや細か い程度で，炭素鋼の場合ほど明確な相違は認められな かった。

次に(c)で述べたように，18-8ステンレス鋼では，同 一加工度でも前加工速度が早い場合のほうが遅い場合 よりも硬度が高く，てのととは(b)で述べた特性と相関 関係にある.18-8ステンレス鋼では冷間加工によって 準安定な $\gamma$ から $\alpha$ へのいわゆるルテンサイト変態を 生ずることから，前加工速度によってマルテンサイト 変態促進の程度に相違を生じ，その結果，同一前加工 度でも前加工速度によって，硬度その他の機械的性質 に差を生ずるのではないかと推定されるので，次の実 験を行なった.

すなわち前加工度7.4\%，34\%および約55\%(破断試 験片の局部収縮を起てしていない部分）の3 種につい て，X線ディフラクトメータによる川渏, 篠田の方法 で, 高速引張前加工材と静的引張前加工材とのマルテ ンサイト量の定量を行なった. その結果を示すと Fig. 11のとおりで，乙の図から高速引張前加工材 (D) のほ

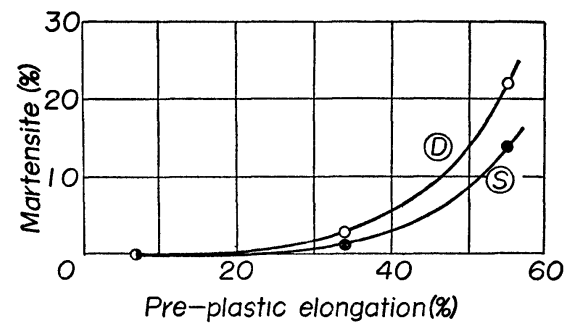

Fig. 11. The transformed martensite wt $\%$ for statically and rapidly stretched $18 \% \mathrm{Cr}-8 \% \mathrm{Ni}$ stainless steel.

うがマルテンサイト変態がより促進されており，しか も，乙の傾向は前加工度の増加とともに著しくなって いる. したがって, 静的引張前加工材に比較して, 高 速引張前加工材のほうが而力, 引張強度, 硬度などの 值が高いのは，主として静的引張前加工の場合より高 速引張前加工によってマルテンサイト変態がより促進 されたととによると考えてよかろう。なお，18-8ステ ンレス鋼を低温で加工すればマルテンサイト変態が促 進されることはよく知られているが，高速変形によっ てもマルテンサイト変態が促進されているととから， 高速変形が低温での加工に類似しているとする一つの 証左といえよう,

\section{4・2 17-4 PH鋼の場合}

顕微鏡観察を行なって，高速引張前加工材と静的引 張前加工材のすべり带の発生状態を比較したが，両者 


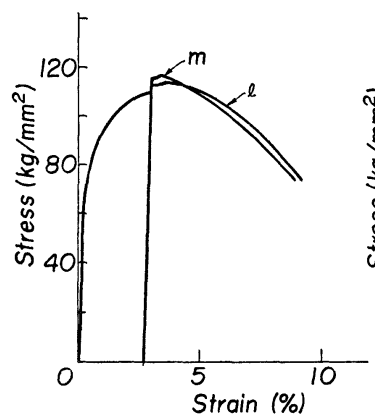

(a)

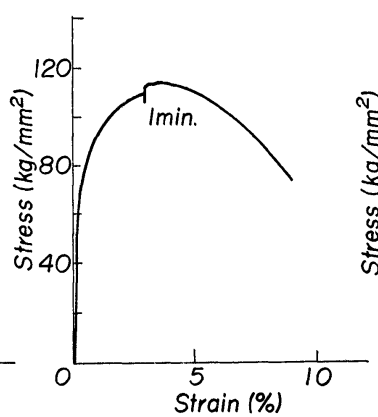

(b)

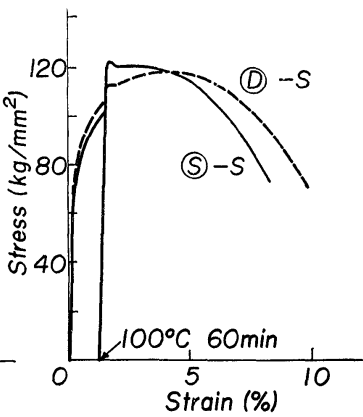

(c)
(a) Stress-strain diagram.
1-curve : Statically pre-strained $(\varepsilon=2.5 \%)$ and immediately stretched.
m-curve : Statically pre-strained $(\varepsilon=2.5 \%)$ and stretched after aging for one day at room temperature
(b) Stress-strain diagram.
Tensile load required to pre-strain $(\varepsilon=2.5 \%)$ was keeped for one minute and stretched again.
(c) Stress-strain diagram.
Dotted line : rapidly pre-strained $(\varepsilon=1.2 \%)$ and statically stretched after aging treatment $\left(100^{\circ} \mathrm{C}, 60 \mathrm{~min}\right)$.
Solid line : statically pre-strained $(\varepsilon=1.2 \%)$ and stretched again after aging treatment $\left(100^{\circ} \mathrm{C}, 60 \mathrm{~min}\right)$.

Fig. 12. Variation of stress-strain diagram for $17 \% \mathrm{Cr}-4 \% \mathrm{Ni} \mathrm{PH}$ stainless steel with testing and aging condition.

の間にほとんど相違か認められなかった。 Fig. 7，8， 10の各 (a) (b) 図を比較して明らかなように，18-8ステ ンレス鋼と17-4 PH鋼とでは耐力, 引張強度, 硬度に 及ぼす前加工速度の影響がまったく逆の関係にある. すなわち18-8ステンレ゙ス鋼では, 同一前加工度でも高 速引張前加工材のほうが静的引張前加工材に比べてよ り強化されているのにもかかわらず，17-4 PH鋼では 逆に静的引張前加工材のほうが強化されている。

てのような強化の起てる原因として, 前加工速度の 相違によって時効進行程度に差を生ずるてとに原因す るのではないかと考えられるので, その点を検討して みた．Fig. 12 (a) は 2 本の試験片のうち，1本は静的 前加工後除荷してからただちにふたたび引張試験した 場合 ( $l$ 曲線) ，他の 1 本は静的前加工して除荷後 常温に 1 日放置してからふたたび引張試験した場合 ( $m$ 曲線) とを比較したものである.1 日経過してから 引張試験した場合のほうが耐力の上昇が大きく, 常温 で時効が進行しているてとがわかる．Fig. 12 (b) は前 引張加工応力直下の状態に 1 分間保持した後ただちに 引張試験した結果であるが，すでに耐力の上昇が認め られるととから, 応力の作用下では時効が進行しやす いととを示している. 次に Fig. 12 (c) は 2 本の試験片 のうち，1 本は $1.2 \%$ 静的引張前加工を与光てから， $100^{\circ} \mathrm{C}, 60$ 分の時效処理を施し, ふたたび静的引張試 験した場合（実線 $(S)-S$ ) と，同じく $1.2 \%$ 高速引張前 加工材に同じ時効処理を施してからふたたび静的引張 試験した場合（点線 (D)-S） とを比較したもので，同 一時効条件に対して静的引張前加工材のほうが著しく 耐力が上昇しており, 高速引張前加工材より時効が促 集されているととがわかる、しかも Fig. 12 (b) の結果
から，応力の作用時間が長いほど時効が進行しやすい ととが推定される。したがって，高速引張前加工材よ りも静的引張前加工材のほうが時効がより促進される 結果, 後者の強度や硬度が前者のそれより高い值を示 すものと解釈してよからう.

以上のてとから，前加工速度によるすべり带の発生 の様相や, 前加工の際に生ずる変態, 時効などに及ぼ す前加工速度の影響を詳細に検討した上でないと, 単 に高速前加工材のほうがかたい（強い）とか, やわら かい（弱い）とかを簡単に断定できないととが明らか となった。

\section{5 結 言}

前加工速度の大小によって, 内部構造に相違が起て るかどうか，それが起とるとすれば高速引張加工材の 機械的性質にいかなる影響を与兄るかを18-8ステンレ ス鋼および17-4 PH鋼の場合について検討した。得ら れた結果を総括すると次のようである.

(1) 18-8ステンレス鋼，17-4 PH鋼とも溶体化処理 材の耐力, 引張強度は静的引張試験の場合に比較して, 高速引張試験の場合のほうが高い值を示し, ひずみ速 度依存性か認められた。

（2） 18-8ステンレス鋼の場合，静的引張前加工材に 比較して高速引張前加工材のほうか耐力, 引張強度, 硬度が高い值を示した。乙れは，主として静的引張前 加工の場合より, 高速引張前加工によってマルテンサ イト変態がより促進されるためであるてとが明らかに された.

（3） 17-4 PH鋼の場合, 高速引張前加工材に比較し て静的引張前加工材のほうか洏力, 引張強度, 硬度が 高い値を示した。とれは主として静的引張前加工材の 
ほうが引張加工応力の作用時間が長く, 高速引張前加 工材よりも著しく時効が促進されるためであるととが ほぼ明らかにされた。

（4）以上のととから，前加工速度の大小によって， ステンレス鋼の内部構造には著しい相違を生じ、それ が前加工材の機械的性質に大きな影響を与えているこ とがわかる。

本研究を遂行するにあたりで助言を賜わった大阪大 学工学部教授篠田軍治博士および火薬を提供していた だいた日本化薬(侏沢田継男博士のご好意に深謝する。

(昭和 40 年 5 月19日 日本材料学会第14期総会講演会にて講演)

\section{参 考 文 献}

1）作井誠太，森勉，日本金属学会会報， 3，303, 358, 405 (1964).

2) 山田厳，杉田忠彰，小寺沢啓司，材料，14，192 (1965).

3) Glark, D.S., and D.S. Wood, Proc. ASTM, 49, 717 (1949).
4) Glark, D.S., Trans. ASM, 46, 34 (1954).

5) 塚田晴一, 井上稔, 桜井武尚, 塑性と加工, 2, 123 (1961).

6) Baron, H.G., Sheet Met. Ind., 39, 257 (1962).

7) 作井誠太, 中村正久，布村成具，鉄と鋼，48，28 (1962).

8）河田幸三，福井伸二，清野次郎，応用物理，32, 742 (1963).

9) Henriksen, E.K., I Lieberman, J.F. Wilkin and W.B. McPherson, ASTM STP, No. 336, 104 (1963).

10）福井伸二，河田幸三，清野次郎，機械学会誌，67, 150 (1964).

11）たとえば Cina, B., J. Iron and Steel Inst., 179, 406 (1954).

12）川崎正，篠田軍治，金属学会誌，22，489 (1958).

13）応用金属学大系 6 , ステンレス鋼・耐熱鋼, p. 64 (1963) 誠文堂新光社 